УДК 004.031.6

\section{МЕТОДИ ЕНЕРГОЗБЕРЕЖЕННЯ В СЕНСОРНИХ МЕРЕЖАХ}

ШКІЛЬ О.С., КОСТЮК С.О., ФІЛІППЕНКО І.В.

Наводяться результати дослідження методів збереження енергії, що використовуються при проектуванні та розробці сучасних сенсорних мереж. Дослідження базується на особливостях сенсорних мереж та питань застосовності загальних практик збереження енергії у вбудованих системах для оптимізації енергоспоживання сенсорних вузлів. Окрема увага приділяється структурі сенсорного вузла та виділенню основних споживачів електричної енергії сенсорного вузла. Наводиться класифікація методів енергозбереження за напрямком їх дії.

Ключові слова: сенсорна мережа, бездротова сенсорна мережа, сенсорний вузол, вбудована система, оптимізація енергоспоживання, методи енергозбереження.

Key words: sensor network, wireless sensor network, sensor node, embedded system, energy usage optimization, energy saving methods.

\section{1. Вступ}

В останні роки спостерігається значне пожвавлення інтересу до сенсорних мереж. Сучасні сенсорні мережі є однією з важливих складових Інтернету речей - глобальної мережі підключених пристроїв зі взаємодіями типу «машина-машина» та широко застосовуються для збирання даних про стан деяких предметів, явищ та процесів. Отримані за допомогою сенсорних мереж дані зберігаються та оброблюються за допомогою статистичного аналізу та нейронних мереж, використовуються для детектування аномалій, моніторингу, автоматизації та покращення корисних характеристик. Зокрема, сенсорні мережі широко застосовуються для збирання даних про стан навколишнього середовища, контролю виробничих процесів та стану обладнання, автоматизації будівель, дому та цілих міст.

Основою сенсорних мереж $є$ сенсорні вузли базові елементи мережі, що виконують вимірювання заданих характеристик та передачу даних для подальшої обробки. Зазвичай такі вузли мають низьку собівартість, малий фізичний розмір та жорсткі обмеження на час автономної роботи.

Такі обмеження у свою чергу випливають 3 ключових особливостей сенсорних мереж - сенсорні вузли встановлюються у великій кількості на деякій території 3 обмеженим доступом. Велика кількість вузлів призводить до необхідності мінімізації початкової вартості окремих вузлів та вартості розгортання усієї системи, а встановлення на території з обмеженим доступом призводить до необхідності мінімізації вартості обслуговування мережі.
3 метою спрощення початкового налаштування та обслуговування сенсорної мережі перевага надається бездротовим сенсорним мережам зі здатністю самоорганізації. Сенсорні вузли в таких мережах мають автономне джерело живлення та бездротовий зв'язок з іншими вузлами мережі за допомогою радіоканалу. Як автономне джерело живлення застосовуються хімічні батареї та енергія навколишнього середовища (сонячна енергія, різниця температур, вібрація тощо) [1].

Для забезпечення тривалої автономної роботи сенсорної мережі, зменшення вартості обслуговування сенсорних мереж при заданих обмеженнях постає завдання оптимального використання та наявної енергії для кожного 3 сенсорних вузлів.

Враховуючи постійне вдосконалення рішень у сфері мікроелектроніки, програмного забезпечення та вбудованих систем, актуальним є дослідження існуючих та вироблення нових засобів енергозбереження у сенсорних мережах.

Метою роботи є дослідження, категоризація, пошук та розробка нових методів енергозбереження у сенсорних мережах з урахуванням сучасних досягнень та вимог у сфері мікроелектроніки, Інтернету речей та вбудованих систем.

\section{2. Джерела витрат енергії у сенсорних вузлах}

Одним 3 основних етапів оптимізації енергоспоживання в сенсорних вузлах можна назвати аналіз складових сенсорного вузла, його фізичних та програмних компонентів, а також виділення основних статей витрат енергії в таких пристроях.

Загалом сенсорні вузли складаються 3 таких компонентів: джерело живлення (Power Source), блок керування живленням (Power Management Unit), блок керування на обробки даних (Control Unit), блок вимірювання (Sensing Unit) та блок зв'язку (Transreceiver). Узагальнена структура сенсорного вузла наведена на рис. 1.

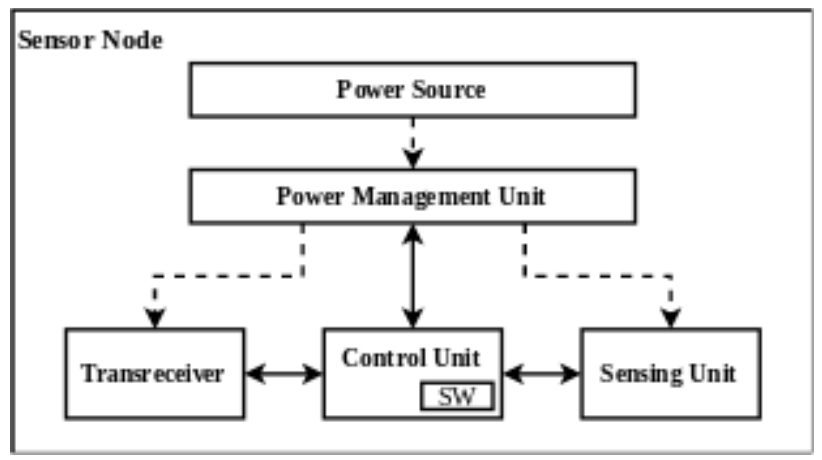

Рис. 1. Загальна структура сенсорного вузла 
Як джерело живлення можуть використовуватися гальванічні елементи (primary cells) та акумулятори (secondary cells). Об'єм гальванічних джерел живлення обмежений, заряджання та відновлення ємкості таких джерел є неможливим, а отже вичерпання ресурсу гальванічного елемента призводить до повного виходу сенсорного вузла із ладу та деградації сенсорної мережі. Цей факт у свою чергу призводить до дуже жорстких обмежень зі сторони енергоспоживання для усіх компонентів сенсорного вузла. Як альтернативне джерело енергії може виступати енергія, забрана спеціальними перетворювачами iз навколишнього середовища (Energy Harvesting). У більшості випадків зібрана енергія використовується для підзарядки акумуляторів та супер-конденсаторів, що виступають як енергетичні буфери. Інколи зібрана енергія використовується безпосередньо без додаткових буферів, наприклад, в технологіях RFID.

Блоки керування живленням використовуються для стабілізації та приведення енергії у придатний для споживання стан (energy conditioning). Такі блоки контролюють об’єми залишкової енергії, перетворюють рівні напруги під вимоги різних компонентів сенсорного вузла, а також сигналізують модуль керування про поточний стан батареї. Необхідність таких блоків пов'язана 3 нелінійними характеристиками елементів живлення та неоднорідністю вимог до енергопостачання елементів сенсорного вузла. Ефективність таких компонентів не є ідеальною: частина енергії витрачається на контроль та перетворення енергії у придатний для споживання стан.

Сенсорний блок безпосередньо відповідає за виконання вимірювань у сенсорних вузлах. Залежно від природи досліджуваного явища показники енергоспоживання таких вузлів сильно відрізняються: від 26 мкВТ у робочому режимі для новітніх акселерометрів до 700 мВт для радарів, 140 мВт для сенсорів зображення та 72 мВт для сенсорів GPS. Також враховується тривалість отримання сенсором одного зразка даних.

Блок зв'язку (Transreceiver) відповідає за двосторонню комунікацію 3 зовнішніми вузлами мережі. Він витрачає енергію на: передачу власних даних, прослуховування ефіру та отримання керуючої інформації. У деяких випадках сенсорний вузол також відповідає за ретрансляцію даних від інших вузлів. Таким чином6 енергія витрачається на додаткове прослуховування ефіру, попередню обробку пакетів та передачу сторонніх пакетів під час ретрансляції. Показники енергоспоживання залежать конкретно від протоколу, потужності передачі та технології виконання блоку зв'язку, причому в режимі прослуховуван- ня може витрачатися більше енергії, ніж у режимі передачі. Наприклад, для SoC nRF24L01+ максимальне енергоспоживання у режимі передачі складає 34 мВт, мінімальне у режимі отримання даних - 38 мВт, а у режимі пасивного прослуховування - 27 мВт. Таким чином, необхідність ретрансляції даних сильно підвищує енергоспоживання вузла, а фонове прослуховування витрачає практично стільки ж енергії, скільки й активне отримання та передача мережевих пакетів.

Зведена інформація щодо типового енергоспоживання для різних протоколів передачі даних, що використовуються у сенсорних мережах, наведена у таблиці [2].

Зведені показники енергоспоживання для типових протоколів передачі даних

\begin{tabular}{|l|l|l|l|}
\hline Протокол & $\begin{array}{l}\text { Швидкість } \\
\text { передачі }\end{array}$ & $\begin{array}{l}\text { Номінальна } \\
\text { відстань, м }\end{array}$ & $\begin{array}{l}\text { Макс. спож. } \\
\text { струму, мА }\end{array}$ \\
\hline ZigBee & 250 кбіт/c & 100 & 30 \\
\hline Wi-Fi & 1 Гбіт/c & 150 & 116 \\
\hline Thread & 250 кбіт/c & 30 & 12.3 \\
\hline Z-Wave & 100 кбіт/c & 30 & 17 \\
\hline BLE (4.x) & 1 Мбіт/с & 10 & 12.5 \\
\hline
\end{tabular}

Блок керування відповідає за реалізацію алгоритмів роботи сенсорного вузла. Він отримує зовнішні сигнали від усіх інших компонентів, відповідає за перемикання режимів роботи, попередню обробку даних, надсилання команд сенсорному блоку, ініціалізацію обміну даними 3 зовнішніми вузлами. Найчастіше як блоки керування використовуються мікроконтролери 3 деякою мікропрограмою (прошивкою, firmware). У деяких випадках мікроконтролер входить до складу SoC разом з блоком зв'язку та виконує обробку мережевих пакетів.

Таким чином, енергоспоживання всього сенсорного вузла можна спрощено представити як суму енергоспоживання кожного $з$ його компонентів:

$$
\mathrm{E}_{\text {total }}=\frac{1}{\alpha} \sum_{\mathrm{i}=1}^{\mathrm{n}} \mathrm{E}_{\mathrm{i}},
$$

де $\mathrm{E}_{\text {total }}$ - загальне енергоспоживання сенсорного вузла; $\alpha$ - коефіцієнт ефективності DC-DC перетворювача напруги у блоці керування живленням; $\mathrm{E}_{\mathrm{i}}-$ енергоспоживання кожного 3 окремих компонентів сенсорного вузла.

При цьому показник енергоспоживання для кожного $з$ компонентів можна спрощено записати як:

$$
\mathrm{E}=\int \mathrm{P}(\mathrm{t}) \mathrm{dt} \approx \mathrm{P}_{\text {saving }} \cdot \mathrm{t}_{\text {saving }}+\mathrm{P}_{\text {active }} \cdot \mathrm{t}_{\text {active }},
$$

де $\mathrm{E}$ - кількість спожитої енергії для окремого компонента; $\mathrm{P}_{\text {saving }}$ - кількість спожитої енергії в одиницю часу в режимі енергозбереження; $t_{\text {saving }}$ - час перебування компонента у активному режимі; $\mathrm{P}_{\text {active }}$ - кількість спожитої енергії в одиницю часу в активному режимі; $t_{\text {active }}$ - час пере- 
бування компонента у активному режимі.

Більш детально питання оцінки енергоспоживання сенсорного вузла у різних режимах роботи розглядається у [3] та [4].

Таким чином, задача оптимізації енергоспоживання сенсорного вузла зводиться до задачі оптимізації енергоспоживання та ефективності кожного 3 його компонентів: блоку керування живленням, сенсорного блоку, блоку зв'язку та мікроконтролера. Методи для зменшення енергоспоживання для кожного 3 елементів сенсорного вузла розглянуті у наступних секціях.

\section{3. Огляд методів енергозбереження в сенсор- них мережах}

Всі методи збереження енергії у сенсорних мережах можна розділити на чотири великі групи: оптимізація циклів сну/роботи (sleep/ wakeup schemes), оптимізація даних (data-driven), оптимізація маршрутів та радіо обміну (radio and routing), а також оптимізація апаратного забезпечення та алгоритмів керування (hardware and control optimization).

Кожна 3 цих категорій включає в себе вкладені категорії. Кожна вкладена категорія має вертикальну характеристику, тобто реалізація окремих схем енергозбереження зачіпає всі рівні реалізації сенсорного вузла: від низького рівня апаратного забезпечення до алгоритмів маршрутизації та програмного забезпечення.

Ілюстрація для запропонованої класифікації представлена на рис. 2.

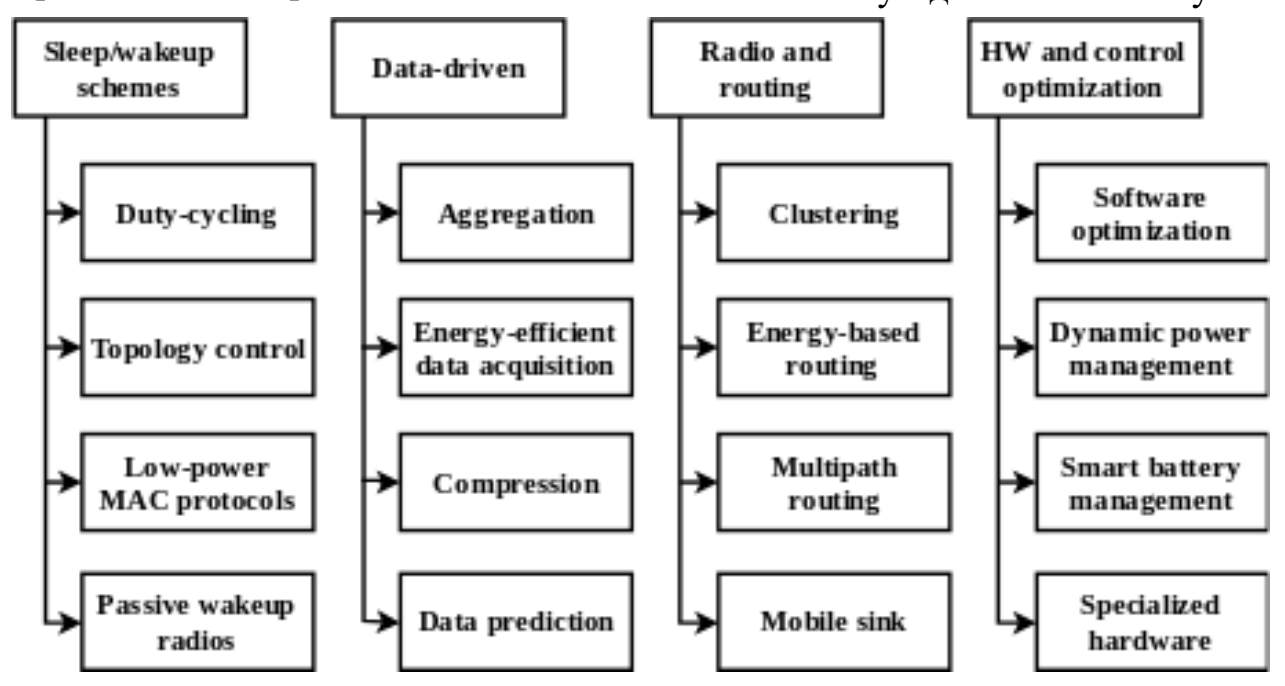
деяких параметрів. rendezvous). вих модулів зв'язку з пасивним пробудженням (passive wakeup radios). Основою таких методів $\epsilon$ алгоритми планування та переключення сенсорного вузла між активним станом роботи та пасивним станом збереження енергії залежно від

Схеми керування робочим циклом визначають алгоритми пробудження сенсорного вузла для забезпечення успішної комунікації, отримання та ретрансляції мережевих пакетів від інших вузлів мережі. Більшу частину власного часу сенсорний вузол перебуває у режимі збереження енергії, а пробудження відбуваються у відповідь на настання деякої події. Таким чином, більшу частину часу вузли не беруть участі у процесі обміну пакетами, а затримка розповсюдження інформації зростає. Пробудження модуля зв'язку відбувається при отриманні пакета від іншого вузла (on-demand), асинхронно у довільні проміжки часу (asynchronous) та синхронно на основі визначеного графіка (scheduled

Детальне дослідження схем керування робочим циклом наведено у роботі [5].

У схемах з керуванням топологією використовується надлишок (redundancy) з'єднань між вузлами сенсорної мережі. При наявності надлишкової кількості вузлів можливо використовувати тільки невелику множину вузлів для передачі даних та справної роботи сенсорної мережі. Тільки невелика підмножина вузлів перебуває у активному стані та здатна до ретрансляції даних у один момент часу. Топологія з'єднань, у свою чергу, адаптується залежно від поточної завантаженості мережі, а надлишкові вузли перемикаються у режим енергозбереження.

Питання оптимального вибору множини активних вузлів $є$ предметом окремих досліджень. Зокрема, у роботі [6] множина активних вузлів визначається на основі залишку доступної енергії. У [7] пропону-

Рис. 2. Категоризація методів збереження енергії в сенсорних вузлах

Серед всіх методів оптимізації циклів сну/роботи можна виділити 4 вкладені категорії: керування робочим циклом (duty cycling), керування топологією мережі (topology control), використання спеціальних протоколів доступу до каналу (lowpower MAC protocols) та використання бездрото- ється розділення вузлів на групи за місцезнаходженням: тільки один сенсор 3 усієї групи сенсорів $\epsilon$ активним у кожний момент часу. до каналу (MAC, media access control) тісно поєднуються питання енергозбереження та організації обміну даними між вузлами, як зазначено нижче.
У енергоефективних схемах керування доступом 
У протоколах 3 розділенням за часом (timedivision multiple access, TDMA-based protocols) доступ до каналу передачі даних розбивається на суворо визначені часові проміжки: сенсорні вузли здатні приймати та відправляти інформацію тільки у межах власного часового проміжку, а увесь інший час вони знаходяться у режимі збереження енергії, не передають та не отримують жодної інформації. Зокрема така схема керування входить до стеку протоколів Bluetooth Low Energy, але рідко використовується у чистому вигляді через вразливість до інтерференції та колізій [5].

Альтернативною схемою керування доступом у сенсорних мережах $є$ керування 3 попередженням «суперечок» (contention-based protocols). Ocновним завданням таких схем $є$ саме попередження колізій. Вони передбачають попереднє прослуховування каналу перед початком передачі та просунуті алгоритми затримки між спробами повторного доступу (back-off algorithms). Серед яскравих представників - протокол IEEE 802.15.4 [8], а також протоколи В-МАC (Berkeley MAC) та S-MAC (Sensor-MAC), описані у роботах [9] та [10] відповідно.

Окремою категорією схем керування робочим циклом $є$ схеми керування 3 застосуванням пасивних модулів бездротового зв'язку, що не споживають електричної енергії у режимі прослуховування. При детектуванні радіосигналу радіо-модуль сповіщає про подію блок керування та пробуджує сенсорний вузол. Одна з реалізацій такого підходу на основі технології RFID описана у роботі [11].

Інша велика категорія методів спрямована на оптимізацію того об'єму даних, які передаються у сенсорній мережі. Розділяються на 4 вкладені категорії: об'єднання даних (aggregation), енергоефективне отримання даних (energy-efficient data acquisition), стискання (compression) та передбачення (data prediction).

У роботі [12] наводяться результати детального дослідження питання об'єднання даних у сенсорних мережах. В них описується процес попередньої обробки та агрегації даних на проміжних вузлах сенсорної мережі, що дозволяє скоротити об'єм даних на передачу та, як результат, скоротити енергетичні витрати у мережі. Як альтернатива може використовуватися стискання (компресія) даних без втрат на вихідних та проміжних вузлах [13].

Методи енергоефективного отримання даних базуються на оптимізації опитування та циклів роботи сенсорних блоків. Як було вказано у розділі 2, сенсорні блоки можуть використовувати об'єми енергії, що перевищують енергоспоживання усіх інших модулів загалом. Для опти- мального використання енергії можуть використовуватися комбінації сенсорів. У роботі [13] наведено приклад спостереження за об'єктом, де для детектування вторгнення пропонується використовувати звукові сенсори та вмикати енергетично дорогі камери тільки при спрацюванні таких енергетично дешевих сенсорів.

Як альтернатива можуть застосовуватися адаптивні алгоритми та методи передбачення даних на основі моделі досліджуваного явища. Один 3 алгоритмів планування вимірювань 3 використанням енергетично дорогих сенсорів запропоновано у роботі [14], а повний огляд методів наведено у [5].

Третя велика категорія методів спрямована на оптимізацію маршрутизації та передачі трафіка довільного розміру між вузлами мережі. У свою чергу, всі такі методи можна поділити на: методи кластеризації (clustering), маршрутизації на основі енергетичних показників (energy-based routing), балансування маршрутів (multipath routing) та методи 3 використанням мобільних вузлів збору даних (mobile sinks)

Алгоритми кластеризації засновані на ієрархічній моделі побудови сенсорної мережі. Вся сенсорна мережа розбивається на окремі незалежні сегменти - кластери. У межах одного кластеру обирається один вузол, що відповідає за координацію роботи та збирає дані від усіх інших вузлів кластеру - cluster head $(\mathrm{CH})$. Таким чином, передача даних від окремих вузлів відбувається на невеликі відстані у чітко визначених межах, що дозволяє зменшити потужність передавачів. Більш того, всі вузли, окрім $\mathrm{CH}$, отримують можливість ігнорувати трафік сторонніх сенсорів та проводити більшу частину часу у режимі енергозбереження. Приклад такої мережі наведено на рис. 3 [14].

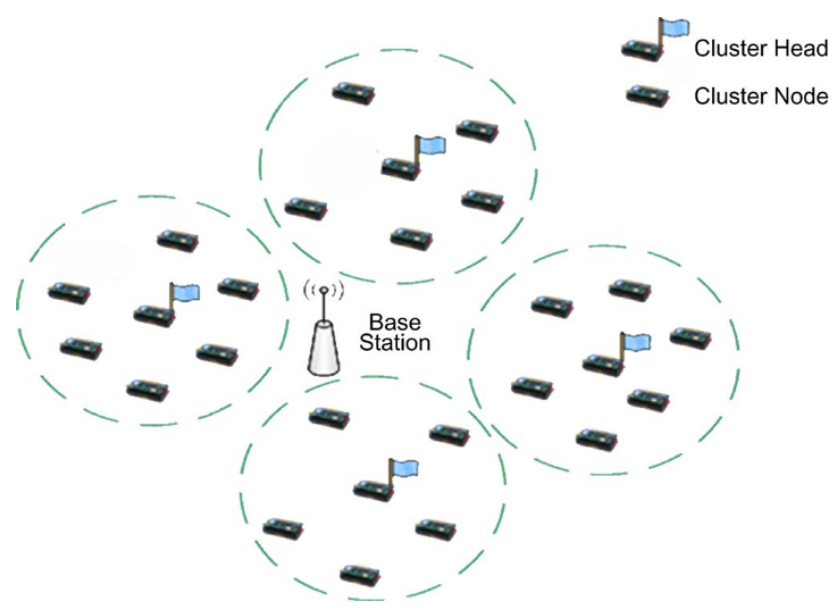

Рис. 3. Кластеризація та визначення головного вузла у кластері (Cluster Head) 
Питання кластеризації та вибору СН широко досліджується у наукових роботах. Зокрема, у роботі [15] запропоновано LEACH - адаптивний протокол $з$ випадковим вибором $\mathrm{CH}$, ротацією СН та об'єднанням даних (data aggregation and reduction). А у роботі [16] запропоновано протокол HEED, що передбачає вибір $\mathrm{CH}$ на основі залишку доступної енергії на вузлах та деякому вторинному параметрі, як, наприклад, близькість до сусідніх вузлів.

Інший підхід - це маршрутизація на основі енергетичних показників. В таких мережах як метрика маршруту від вимірювального вузла до точки збору даних застосовується кількість залишкової енергії. Одна 3 можливостей застосування такої метрики досліджується у роботі [17].

Методи балансування маршрутів засновані на періодичній ротації проміжних вузлів ретрансляції для попередження передчасного виснаження енергетичних запасів вузлів. А методи 3 мобільним вузлом збору даних дозволяють скоротити маршрут передачі даних від вузла, що безпосередньо виконує вимірювання до вузла збору даних [13].

Як зазначено вище, різноманітні методи оптимізації циклів сну/роботи, оптимізації даних, маршрутів та радіообміну використовують складні алгоритми контрою та обробки даних на вузлах мережі, а також потребують апаратної підтримки режимів сну та пробудження вузла. Таким чином, постає питання оптимізації блоку керування сенсорним вузлом, а саме його апаратного та програмного забезпечення.

До групи методів оптимізації апаратного забезпечення та алгоритмів блоку керування (hardware and control optimization) входять методи оптимізації програмного забезпечення (software optimization), динамічне керування енергопостачанням (dynamic power management), застосування спеціалізованого апаратного забезпечення (specialized hardware), а також методи оптимального використання джерел енергії, зокрема акумуляторів (battery management).

Методи оптимізації програмного забезпечення (ПЗ) спрямовані на оптимізацію програмних реалізацій алгоритмів керування та обробки даних в сенсорних вузлах. У роботі [18] описуються стандартні способи оптимізації ПЗ на рівні алгоритмів, сирцевого коду та інструкцій. У [19] досліджується вплив методів оптимізації на енергоспоживання, швидкість та розмір вбудованого ПЗ.

Серед проблем написання енергетичноефективного програмного забезпечення у роботі [20] називається загальна складність програмного коду, використання абстракцій високого рівня та закритих бібліотек від виробників апаратного забезпечення, що ускладнюють аналіз енергоефективності окремих програмних рішень. Також авторами відмічається важливість оптимального використання апаратних ресурсів та апаратних режимів збереження енергії.

Разом 3 методами написання енергетично ефективного програмного забезпечення використовуються методи динамічного керування енергопостачанням. У роботі [21] відмічається, що в електронних схемах на базі технології КМОН (CMOS) зростання споживання енергії є пропорційним до зростання тактової частоти та квадрату напруги.

Отже, для зменшення енергоспоживання доцільно використовувати динамічне керування напругою та тактовою частотою елементів сенсорного вузла. Вичерпний огляд сучасних методів динамічного керування енергопостачанням $\mathrm{y}$ комбінації 3 механізмами планування в операційних системах реального часу наведено у роботі [22]. Зі сторони апаратного забезпечення необхідно приділяти увагу ефективності DC-DC перетворювача та блоку керування живленням взагалі.

Окрему увагу при проектуванні та розробці сенсорного вузла слід приділяти характеристикам того джерела енергії, що використовується у проекті. Справа в тому, що характеристика джерел енергії не є лінійною та потребує адаптації використання у апаратній та програмній реалізації пристрою.

Наприклад, у роботі [4] згадується про характеристики батарейних елементів та пропонується метод оцінки часу автономної роботи залежно від показників стуму та напруги. А у роботі [23] пропонується використовувати суперконденсатори як енергетичні буфери для зменшення динамічного навантаження на батарейний елемент та збільшення часу автономної роботи.

У той самий час стратегії використання відновлюваної енергії сонця, вібрації та інших джерел за технологією збору енергії (energy harvesting) разюче відрізняються від стратегій використання джерел 3 фіксованим об’ємом енергії. Наприклад, за наявності надлишку енергії та відсутності буферних елементів може стояти завдання максимально швидкої утилізації отриманої енергії. Більш детально питання оптимального використання зібраної енергії досліджується у роботах [1] та [24].

Однак в деяких випадках вирішити питання енергоспоживання чисто програмними методами не $\epsilon$ можливим: деякі завдання потребують виконання складних алгоритмів та проведення обчислень, для виконання яких стандартні блоки мікроконтролерів не є пристосованими. Таким чином, з'являється необхідність у використанні 
спеціалізованих обчислювачів, блоків керування та обробки.

Серед найбільш поширених та універсальних блоків для сучасних систем на кристалі (system on chip, SoC) можна відмітити апаратні блоки шифрування інформації. Вони використовуються у інтегрованих рішеннях для реалізації захищених протоколів Bluetooth Low Energy та ZigBee, a також входять до складу незалежних блоків керування.

У роботі [25] пропонується повністю спеціалізоване рішення на основі програмованої логіки (FPGA). На одному кристалі FPGA реалізований програмний мікропроцесор (soft core), блок керування енергопостачанням (комбінований блок Power Management Unit 3 DVFS та Clock Gating) та блок прискорення задач управління операційної системи (Cooperative Custom Unit). Проте результати дослідження та дані про ефективність розробленого рішення у роботі не опубліковані.

Автори роботи [26] пішли ще далі та переклали більшу частину роботи щодо контролю та обробки на спеціалізований блок керування. У запропонованому рішенні мікроконтролерне ядро загального призначення $\epsilon$ вимкненим більшу частину власного часу. Вся обробка вхідних подій, рішення про активацію окремих вузлів пристрою та комунікація за модулем зв'язку виконується спеціалізованим модулем обробки подій (event processor). Ілюстрація архітектури такого рішення приведена на рис. 4 [26].

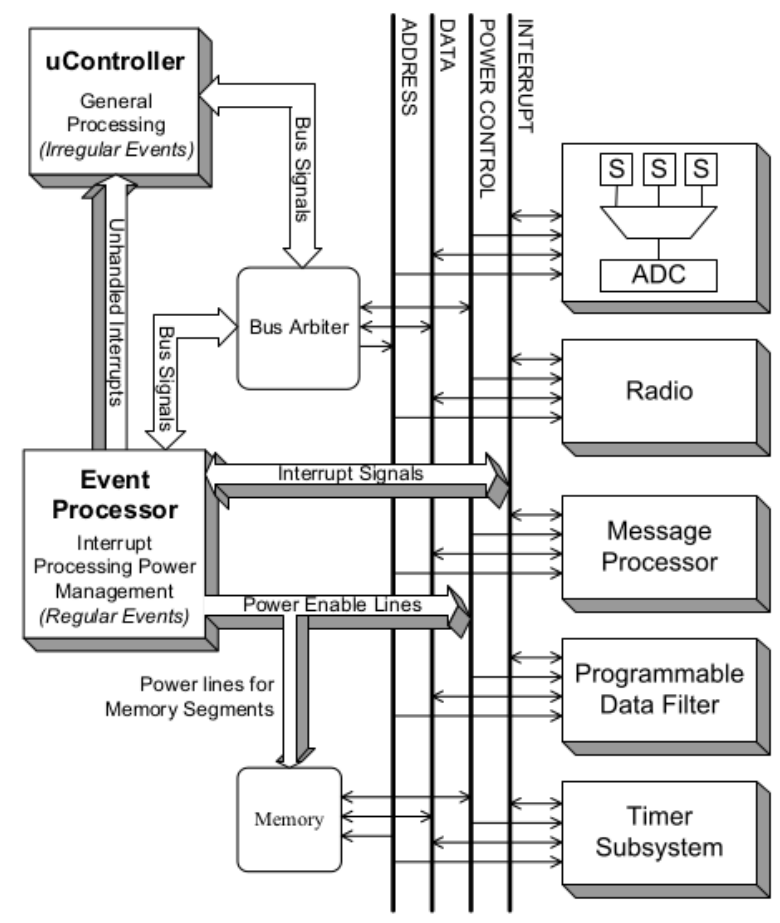

Рис. 4. Ілюстрація внутрішньої архітектури апаратного рішення зі спеціалізованим контрольним блоком
Сучасна технологічна база дозволяє розвинути ідеї апаратного прискорення та використовувати складні апаратні прискорювачі та ефективні реалізації нейронних обчислювачів на основі ПЛІС.

Більш детальний огляд сучасних апаратних методів збереження енергії в сенсорних вузлах, включаючи використання спеціалізованих обчислювачів на основі FPGA, наведено у роботі [27].

Отже, є велике розмаїття методів збереження та оптимального використання енергії в сенсорних мережах. Кожний метод спрямований на оптимізацію окремих аспектів роботи мережі та має власну зону застосовності. Рішення про застосування кожного 3 методів у конкретній реалізації сенсорної мережі приймається у результаті аналізу вимог та особливостей створюваної мережі.

\section{4. Висновки}

Запропоновано класифікацію методів збереження енергії за напрямком їх дії. Проведено огляд засобів збереження енергії на основі оптимізації циклів роботи сенсорно вузла, оптимізації об'єму даних, що передаються у системі, оптимізації маршруту, програмного та апаратного забезпечення пристрою. Наведено окремі приклади технологій збереження енергії для кожної з груп методів та посилання на попередні огляди.

В процесі роботи зроблено висновки про наявність спеціалізації методів збереження енергії. Відмічено, що кожен $з$ методів оптимізації має власну зону застосовності та часто передбачає підвищення складності реалізації, зменшення точності вимірювань, збільшення затримок та погіршення окремих характеристик роботи сенсорної мережі в обмін на кращі показники енергоспоживання та збільшення часу автономної роботи окремих вузлів.

У ході дослідження відмічено пожвавлення інтересу індустрії до апаратних методів збереження енергіï. У порівнянні 3 чисто програмними та алгоритмічними підходами, методи апаратного прискорення та оптимізації дозволяють проводити складну обробку отримуваних даних без втрат у швидкодії та збільшення затримки розповсюдження інформації. Крім того, локальна обробка даних дозволяє зменшити об'єм вихідних даних і зменшити навантаження на мережу та проміжні вузли пересилання даних, а як результат - зменшити витрати на організацію зв'язку між вузлами мережі. 
Таким чином, апаратні способи оптимізації дозволяють досягти найкращих результатів для сенсорних мереж з обробкою відео, звуку та інших складних даних. Метою подальших досліджень можна назвати створення спеціалізованих обчислювачів, щоб перенести частку енергетично дорогих обчислень на енергоефективну апаратну реалізацію.

\section{Література:}

1. Khan J.A. Energy management in Wireless Sensor Networks: A survey / J.A. Khan, H.K. Qureshi, A. Iqbal // Computers \& Electrical Engineering. 2015. T. 41. P. 159176.

2. Samuel S.S.I. A review of connectivity challenges in IoT-smart home / S.S.I. Samuel // 3rd MEC International Conference on Big Data and Smart City (ICBDSC), 15-16 March 2016 Muscat, Oman, 2016. C. 364-368.

3. Halgamuge M.N. An Estimation of Sensor Energy Consumption / M.N. Halgamuge, M. Zukerman, K. Ramamohanarao // Progress In Electromagnetics Research B. 2009. T. 12. P. 259-295.

4. Rodrigues L. Estimating the Lifetime of Wireless Sensor Network Nodes through the Use of Embedded Analytical Battery Models / L. Rodrigue, C. Montez, G. Budke, F. Vasques, P. Portugal. // Journal of Sensor and Actuator Networks. 2017. T. 6, № 2. P. 2.

5. Anastasi $G$. Energy conservation in wireless sensor networks: A survey / G. Anastasi, M. Conti, M. Di Francesco, A. Passarella // Ad Hoc Networks. 2009. T. 7, № 3. P. 537-568.

6. Karasabun E. Active node determination for correlated data gathering in wireless sensor networks / E. Karasabun, I. Korpeoglu, C. Aykanat // Computer Networks. 2013. T. 47, №. 5. C. 1124-1138.

7. Misra S. Connectivity preserving localized coverage algorithm for area monitoring using wireless sensor networks / S. Misra, M. Pavan Kumar, M.S. Obaidat // Computer Communications. 2011. T. 34, № 12. P. 1484 1496.

8. Baronti P. Wireless sensor networks: A survey on the state of the art and the 802.15.4 and ZigBee standards / P. Baronti, P. Pillai, V.W.C. Chook, S. Chessa, A. Gotta, Y. F. Hu // Computer Communications. 2007. T. 30, № 7. P. 1655-1695.

9. Polastre $J$. Versatile low power media access for wireless sensor networks / J. Polastre, J. Hill, D. Culler // Proceedings of the 2nd International Conference on Embedded Networked Sensor Systems - SenSys '04, 3-5 November 2004. Baltimore, USA, 2004. P. 95-107.

10. $Y e W$. Medium Access Control With Coordinated Adaptive Sleeping for Wireless Sensor Networks / W. Ye, J. Heidemann, D. Estrin // IEEE/ACM Transactions on Networking. 2004. T. 12, № 3. P. 493-506.

11. $B a H$. Passive wake-up radios: From devices to applications / H. Ba, I. Demirkol, W. Heinzelman // Ad Hoc Networks. 2013. T. 11, № 8. C. 2605-2621.

12. Fasolo E. In-network aggregation techniques for wireless sensor networks: a survey / E. Fasolo, M. Rossi, J. Widmer, M. Zorzi // IEEE Wireless Communications. 2007. T. 14, № 2. P. 70-87.

13. Rault $T$. Energy efficiency in wireless sensor networks: A top-down survey / T. Rault, A. Bouabdallah,
Y. Challal // Computer Networks. 2014. T. 67. P. 104122.

14. Alippi C. An Adaptive Sampling Algorithm for Effective Energy Management in Wireless Sensor Networks With Energy-Hungry Sensors / C. Alippi, G. Anastasi, M. Di Francesco, M. Roveri // IEEE Transactions on Instrumentation and Measurement. 2010. T. 59, № 2. C. 335-344.

15. Heinzelman W.R. Energy-efficient communication protocol for wireless microsensor networks / W.R. Heinzelman, A. Chandrakasan, H. Balakrishnan // Proceedings of the 33rd Annual Hawaii International Conference on System Sciences, 7 January 2002. Maui, HI, USA. 2002. C. 364-368.

16. Younis $O$. HEED: a hybrid, energy-efficient, distributed clustering approach for ad hoc sensor networks / O. Younis, S. Fahmy // IEEE Transactions on Mobile Computing. 2004. T. 3, № 4. C. 366-379.

17. Shah R.C. Energy aware routing for low energy ad hoc sensor networks / R.C. Shah, J.M. Rabaey // 2002 IEEE Wireless Communications and Networking Conference Record. WCNC 2002 (Cat. No.02TH8609), 17-21 March 2002 - Orlando, FL, USA. 2002.

18. Ortiz D.A. Impact of source code optimizations on power consumption of embedded systems / D.A. Ortiz, N.G. Santiago // 2008 Joint 6th International IEEE Northeast Workshop on Circuits and Systems and TAISA Conference, 22-25 June 2008. Montreal, QC, Canada. 2008. P. 133-136.

19. Dalal $V$. Software power optimizations in an embedded system / V. Dalal, C. P. Ravikumar // VLSI Design 2001. Fourteenth International Conference on VLSI Design, 7 January 2001 - Bangalore, India, 2001. P. 254-259.

20. Georgiou K. The IoT energy challenge: A software perspective / K. Georgiou, S. Xavier-de-Souza, K. Eder // IEEE Embedded Systems Letters. 2017. T. 10, № 3. P. 53-56.

21. Alioto M. Ultra-Low Power VLSI Circuit Design Demystified and Explained: A Tutorial / M. Alioto // IEEE Transactions on Circuits and Systems I: Regular Papers. 2012. T. 59, № 1. C. 3-29.

22. Dargie $W$. Dynamic Power Management in Wireless Sensor Networks: State-of-the-Art / W. Dargie // IEEE Sensors Journal. 2012. T. 12. № 5. C. 1518-1528.

23. Lin X. Power supply and consumption co-optimization of portable embedded systems with hybrid power supply / X. Lin, Y. Wang, N. Chang, M. Pedram // 2014 IEEE 32nd International Conference on Computer Design (ICCD), 19-22 October 2014 - Seoul, South Korea, 2014. P. 477-482.

24. Kansal A. Dynamic Power Management in Wireless Sensor Networks: State-of-the-Art / A. Kansal, J. Hsu, S. Zahedi, M.B. Srivastava // ACM Transactions on Embedded Computing Systems. 2007. T. 6, № 4.32 p.

25. Patil V.S. FPGA Based Power Saving Technique for Sensor Node in Wireless Sensor Network (WSN) / V.S. Patil, Y.B. Mane, S. Deshpande // Computational Intelligence in Sensor Networks. Studies in Computational Intelligence / B. Mishra, S. Dehuri, B. Panigrahi, A. Nayak, B. Mishra, H. Das. Springer, Berlin, Heidelberg, 2019. Chapter 16. P. 385-404. 
26. Hempstead $M$. An Ultra Low Power System Architecture for Sensor Network Applications / M. Hempstead, N. Tripathi, P. Mauro, Gu-Yeon Wei, D. Brooks // 32nd International Symposium on Computer Architecture (ISCA'05), 4-8 June 2005 - Madison, WI, USA. 2005. P. 208 - 219.

27. Cheour $R$. Recent Trends of FPGA Used for LowPower Wireless Sensor Network / R. Cheour, S. Khriji, D.E. Houssaini, M. Baklouti, M. Abid, O. Kanoun // IEEE Aerospace and Electronic Systems Magazine. 2019. T. 34, №. 10. Р. 28-38.

Надійшла до редколегії 12.09.2019

Рецензент: д-р техн. наук, проф. Кривуля Г.Ф. Шкіль Олександр Сергійович, канд. техн. наук, доцент кафедри АПОТ ХНУРЕ. Наукові інтереси: діагностика цифрових систем, дистанційне навчання. Адреса: Україна, 61166, Харків, пр. Науки, 14, тел. 702-13-26.

Костюк Сергій Олександрович, магістрант, кафедра АПОТ ХНУРЕ. Наукові інтереси: ІоТ-системи, бездротові сенсорні мережі. Адреса: Україна, 61166, Харків, пр. Науки, 14, тел. 702-13-26, е-mail: contact@s-kostyuk.me.
Філіппенко Інна Вікторівна, канд. техн. наук, доцент кафедри АПОТ ХНУРЕ. Наукові інтереси: проектування цифрових пристроїв на базі мікроконтролерів, цифрові фільтри. Адреса: Україна, 61166, Харків, пр. Науки, 14, тел. 702-13-26.

Shkil Alexander Sergeevich, $\mathrm{PhD}$, Associate Professor, Design Automation Department, NURE. Scientific interests: diagnostics of digital systems, distance education. Address: Ukraine, 61166, Kharkiv, Nauky Ave. 14, tel. 702-13-26.

Kostiuk Serhii Oleksandrovych, Master Student, Design Automation Department, NURE. Scientific interests: IoT systems, embedded systems. Address: Ukraine, 61166, Kharkiv, Nauky Ave. 14, tel. 702-13-26, e-mail: contact@s-kostyuk.me.

Filippenko Inna Victorovna, $\mathrm{PhD}$, Associate Professor, Design Automation Department, NURE. Scientific interests: design based on microcontrollers, digital filters. Address: Ukraine, 61166, Kharkiv, Nauky Ave. 14, tel. 702-13-26. 